\title{
Close Encounters: the role of culture in interrogation and questioning in the Second World War
}

\author{
Simona TOBIA \\ University College London
}

Lyman B. Kirkpatrick spent the Second World War in the American intelligence, working for G-2 and for the Office of Strategic Services (OSS). After the war he served in the Central Intelligence Agency (CIA) and became executive director in 1961. He was also a prolific writer and in 1961 he wrote for the CIA a report titled "Combat Intelligence: a comparative report" which focused on WWII and had the purpose to: "obtain first-hand judgments from intelligence officers at all levels about what methods of intelligence collection had proved most valuable in combat". Unlike us historians, he was able to access sources only available to a CIA officer, including classified documents, visits to G-2 sections of all the armies that had served in the war to conduct interviews and submit questionnaires, and he found that

\begin{abstract}
By far the most profitable source of intelligence for all levels of the command division, corps, and army - was prisoners of war. Some units estimated that as high as 90 per cent of their useful information came from prisoner interrogation. The corps calculated that from 33 to 50 per cent of all the information they received was provided by the interrogators in the prisoner-of-war cages ${ }^{1}$.
\end{abstract}

Historians studying intelligence in the Second World War have traditionally focused on signals intelligence (SIGINT): the impact of programs such as ULTRA, institutions such as the British Government Code and Cypher School at Bletchley Park and devices such as the Enigma machine in breaking encrypted enemy communications are well known by the public beyond academic circles, and so are the networks of spies and the famous 'double-cross system'. It is only recently that historians have turned their gaze to the role human intelligence (HUMINT) in the Second World War' ${ }^{2}$ The publications resulting from the academic project Languages at $\mathrm{War}^{3}$, for instance, offer a reflection on the role of culture, especially language skills, on intelligence collection. In addition, a number of studies have appeared following the declassification, in the early 2000s, of tens of thousands of pages of secret files from both the British and

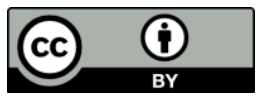

Article received at 28-09-2015 and accepted for publication at 19-12-2015.

1. Lyman B. KIRKPATRICK, Combat Intelligence: a comparative report, Washington, DC, Central Intelligence Agency, 1961, p. 45.

2. On intelligence in the Second World War see, among the many works, Christopher ANDREW, The Defence of the Realm: The Authorized History of Mi5, London, Allen Lane, 2009; F.H. HINSLEY and C.A.G. SimKINS, British Intelligence in the Second World War. Volume Four: Security and CounterIntelligence, London, HMSO, 1990; Keith JEFFERY, Mi6. The History of the Secret Intelligence Service, 1909-1949, London, Bloomsbury, 2010.

3. Hilary FootitT and Michael Kelly (eds), Languages and the military. Alliances, occupation and peace building, Basingstoke, Palgrave MacMillan, 2012; Hilary FootiTT and Michael Kelly (eds), Languages at war. Policies and practices of language contacts in conflict, Basingstoke, Palgrave MacMillan, 2012; Hilary FoотітT and Simona TовіA, WarTalk. Foreign languages and the British war effort in Europe, 1940-47, Basingstoke, Palgrave MacMillan, 2013; Christopher ANDREW and Simona TOBIA, Interrogation in war and conflict: a comparative and interdisciplinary analysis, London, Routledge, 2014. 
American archives. For example the German historian Sönke Neitzel published Soldaten in $2012^{4}$ after discovering the transcripts of secretly recorded conversations between German prisoners of war in British and American interrogation centres. The British journalist Ian Cobain was able to obtain the declassification of the secret archival files, publishing the results firstly in the Guardian and then in his book Cruel Britannia $^{5}$ where he talks about some instances of ill-treatment. There are also a number of efforts to reconstruct the dynamics of interrogation in studies done within American military intelligence schools such as the National Defence Intelligence College ${ }^{6}$. These are just a few examples, but most of the studies published in the wake of this new interest in interrogation and interrogation centres are mostly based on official archival documents ${ }^{7}$, and focus on issues such as the methods of intelligence collection and the value of the information thus collected. This article, besides arguing the importance of interrogation in intelligence during the Second World War, focuses on the role of culture in HUMINT in the European theatre of operations, and it argues that cultural issues, including but not limited to language knowledge, provided an added value to interrogation, interviewing and questioning during and after the Second World War, for example through the employment of native speakers, in particular former refugees and enemy aliens. But this also entailed certain flaws, and it sometimes resulted in bad prisoner handling and therefore bad intelligence collection. This article tries to complement archival sources with personal accounts and oral histories in order to achieve a deeper understanding of the role of the human being in the collection of intelligence through interrogation and questioning.

\section{HUMINT and interrogation in the Second World War}

Interrogation raises moral questions and it can be approached from many angles: for example there are important differences between debriefings by professional intelligence operatives, interrogation by ordinary soldiers, and interviews intended to generate forensic evidence. Interrogation is often the first contact between actors who

4. Sönke NeITZEL and H. WELZER, Soldaten. On fighting, killing and dying. The secret WWII tapes of German POWs, London, Simon \& Shuster, 2012.

5. Ian CoBAIN, Cruel Britannia. A secret history of torture, London, Portobello Books, 2012.

6. Alexander D. CORBIn, The history of Camp Tracy, Fort Belvoir VA, Ziedon Press, 2009; CENTER FOR STRATEGIC INTELLIGENCE RESEARCH, Educing information. Interrogation, science and art: foundations for the future, Washington DC, Center for Strategic Intelligence Research, National Defense Intelligence College, 2006; CENTER FOR STRATEGIC INTELLIGENCE RESEARCH, Interrogation. World War II, Vietnam, Iraq, Washington DC, Center for Strategic Intelligence Research, National Defense Intelligence College, 2008; Steven M. KLEINMAN, "The History of MIS-Y: U.S. Strategic Interrogation During World War II", Master's thesis, Joint Military Intelligence College Washington, DC 2002; DEPARTMENT OF THE ARMY, U.S. Army Intelligence and Interrogation Handbook. The official guide on prisoner interrogation, Guilford, The Lyons Press, 2005.

7. Falko BELL, "'Die deutsche Spionage ist auf Zack'. German Soldiers speak about Intelligence Services (1939-1945)", Journal of Intelligence History, 12:1 (2013) pp. 49-59; Falko BELL, "'One of our Most Valuable Sources of Intelligence': British Intelligence and the Prisoner of War System in 1944", Intelligence and National Security, (2015); Christian B. BAK, "Second World War interrogations and British foreign intelligence: the case of ELGAR", in R. GELlATELY (ed), The Nuremberg interviews. An American psychiatrist's conversations with the defendants and witnesses, London, Pimlico-Random House, 2006; Richard OVERY, "Instructive for the future: the interrogation of the major war criminals in Germany, 1945", in ANDREW and TOBIA, Interrogation in war and conflic.; Richard OvERY, Interrogations: the Nazi elite in Allied hands, London, Allen Lane, 2001; J. Ryan STACKHOUsE, "Gestapo interrogations: myths and realities" in ANDREW and TOBIA, Interrogation in war and conflict. 
come from different cultures and speak different languages. It sets out to elicit information, but the absorption of this information depends on the interrogator's cultural background and conceptual schemes.

During conflict the need to find information about the enemy is essential and interrogating those who might hold this information - obtaining human intelligence HUMINT - can be a vital necessity. According to the NATO Glossary of Terms and Definitions, it is "a category of intelligence derived from information collected and provided by human sources" ${ }^{\prime}$. Today, the British Army publicly defines the work of HUMINT specialists as follows:

HUMINT specialists work in a systematic and controlled way to assimilate crucial pieces of intelligence from people such as refugees, prisoners of war, or the local people who live in the area where the Army is operating. HUMINT operators provide commanders with timely, accurate and often unique intelligence on an enemy's intentions, capabilities and way of working ${ }^{9}$.

The collection of HUMINT may be done openly by interrogating prisoners of war, gathering information from captured documents, accurate screening of sources (enemy aliens, deserters, or any available source considered useful), informers and debriefing, or through clandestine means such as espionage, or again with reconnaissance and surveillance activities conducted by special operations forces. Very often, it involves face-to-face encounters with the enemy at different stages of conflicts, in the context of interrogations, interviews and questioning.

The word interrogation has a somewhat sinister meaning, sometimes it is even understood as a synonymous of torture, especially after the use of the so-called enhanced techniques by military interrogators in American and British interrogation centres in Iraq and at Guantanamo has constantly appeared in the news and has revived the debate on what is permissible in a vicious conflict against a brutal enemy. It is not easy to find a straightforward definition of the term as it is understood by the military, and which is publicly accessible. In 2009 Harvard University's Belfer Center published a memorandum ${ }^{10}$ to provide the members of the new Obama administration with guidelines for interrogations by military or intelligence agencies interrogation is defined as

The systematic effort to procure information to answer specific collection requirements by direct and indirect questioning techniques of a person who is in the custody of the forces conducting the questioning.

And its goal is "to obtain usable and reliable information, in a lawful manner and in the least amount of time, which meets intelligence requirements of any echelon of command"11.

In the Second World War the importance of interrogation in the collection of human intelligence escalated, becoming perhaps the most effective tool to gather information, as thousands and thousands of interrogations were performed throughout

8. NATO, Glossary of terms and definitions, 2013, available at <http://nsa.nato.int/nsa/zPublic/ap/aap6/AAP-6.pdf> (downloaded in August 2013), p. 2H5.

9. Army website, <https://www.army.mod.uk/intelligence/32235.aspx> (last accessed Sept. 10 2015).

10. E. Rosenbach and A.J. Peritz, "Confrontation or collaboration? Congress and the intelligence community. Interrogations and intelligence", <http://belfercenter.ksg.harvard.edu/files/interrogations.pdf〉, 2009 (last accessed Sept.2015).

11. Ibidem, p. 2. 
the conflict and in its aftermath; these were also very peculiar types of intercultural encounters, the purpose of which was not to kill the enemy, but to obtain viable information. These events were intercultural because they generally happened between members of the two opposed armed forces, who met face to face not with the purpose to kill each other, but to exchange (or resist the exchange of) information. In intelligence the tension between the operational need for enemy cultural knowledge (including but absolutely not limited to language knowledge) and the need to trust the loyalty of intelligence officers who are so close to the enemy culture is perhaps one of the most difficult issues to solve: how can a state recruit suitably loyal language intermediaries and manage the balance between trust and familiarity with the culture and language of the enemy? In the Second World War it was the very nature of the conflict that made a solution to this problem possible: the huge number of refugees from Germany and other Nazi occupied countries who potentially responded to all of these requirements for intelligence work - loyalty to the state - which was proved by their hatred of the enemy. As Lt. Col. Robin Stephens, director of the British interrogation centres where Nazi spies were turned into double-agents used to say, the main requirement for an intelligence officer was: "an implacable hatred of the enemy [...] the interrogator must treat each spy as a very individual case, for that matter, a very personal enemy" 12 - not very hard for those who had had to leave their countries, many of whom had had their families interned in concentration camps if not exterminated; and deep knowledge of the enemy's culture and language. And this cultural knowledge provided an added value to the whole intelligence machinery to a scale which was experienced for the first time.

From the Nazi rise to power in 1933 to V-E day more than 340,000 Jews emigrated from Germany and Austria, and despite the well known restrictions in immigration quotas - especially in the US - tens of thousands of them managed to reach safe shores overseas, in Britain or in America. Most likely, between 100 and 150 thousand refugees managed to legally enter the US, and about 75,000 German and Austrian Jews had come to Britain running away from Nazi oppression. Leaving aside the thousands of Jews who joined the partisans and the resistance across Europe, approximately 1.5 million Jews served in regular allied armies (a third of which, 500550,000 , only in the US armed services), and some of them were refugees from Germany, Austria or other Nazi occupied countries ${ }^{13}$. In Britain, approximately 10,000 of them enlisted in the British forces, swore allegiance to King George VI and became known as the King's most loyal enemy aliens ${ }^{14}$. Former refugees joining the American forces also had to be naturalized during training, to then be able to join the fight. During the war the typical destination of these former enemy aliens was in intelligence work, either interrogating captured prisoners of war behind the frontline or translating documents and writing long reports in centres far from the frontline. At the end of the conflict, the vast majority of these loyal aliens had to remain or to go back to their countries of origin to join the denazification effort.

12. Oliver HoAre, Camp 020. MI5 and the Nazi spies, Richmond, Public Record Office, 2000, p. 7.

13. See Atina Grossmann, Jews, Germans and Allies. Close encounters in occupied Germany, Princeton, Princeton University Press, 2009.

14. On Britain's so-called loyal aliens see the books by Helen FRY, mostly based on personal interviews with former refugees from Germany and Austria who joined the British war effort, in particular The King's most loyal enemy aliens. Germans who fought for Britain in the Second World War, Stroud, Stutton, 2007; Churchill's German Army, Stroud, History Press, 2009; Denazification : Britain's enemy aliens, Nazi war criminals and the reconstruction of post-war Europe, Stroud, History Press, 2010; The M room: secret listeners who bugged the Nazis in WW2, North Charleston, NC, Createspace, 2012. 
As we know, Special Operations Executive (SOE) and SIGINT played a crucial role in this conflict, for the first time on such a scale, but intelligence also relied on an impressive HUMINT apparatus, with a number of interrogation centres both in Britain, in the United States and in the various war theatres.

\section{At the frontline}

The situations where officers found themselves face to face with enemies to interrogate, interview or question were many, but the first step was undoubtedly strategic interrogation of captured enemies, which took place immediately behind the frontline during advance in the European theatre and in the Mediterranean theatre. This was done both by especially recruited and trained officers of the British Intelligence Corps or the American G-2 section and Counter-Intelligence Corps (CIC) who were attached to the various units going into combat at the frontline, but occasionally it could also be done by soldiers (sometimes from the infantry) who had the necessary skills to do it even if it was not their primary task and they had not been trained for that. In these situations, operators usually had to deal with large numbers of prisoners, who were questioned to check if they had any useful information, and then were moved back quickly, further from the frontlines.

Colin was too old to be transported to the United Kingdom with the Kindertransport, but he was attached to it on the basis that his father had lost his life at Dachau concentration camp in 1937. Once in Britain, he soon enrolled in the Pioneer Corps, and was then chosen to train with the Commandos. He said that "We [refugees] very much felt that the war was our business and we didn't want to leave it to others" 15 . He was going to be part of a troop of Commandos of German speakers, who would then each join a different troop, and in his case, loyalty was assessed with questions regarding motivation, and vetting was quite a lengthy process. From that moment, Colin only spoke English because "they wanted us to seem British, they didn't want the enemy to know that there were German speaking units" and he considered himself as one of the "British soldiers. The actual nationality ceased to matter". For Colin, interrogation "was what I was there for" although he had only very little specific training in it. In Greece his experience of the war was "very fluid and very mobile", with little time to actually interrogate the prisoners, but later in Albania "we had more contact and there yes, it was not so much a matter of interrogations, it was a matter of [...] er [...] almost being on a friendly basis, chatting and making the most of it. With some exceptions." 16

Gerd came to the States in 1938, after being forced to leave his hometown Cologne. After Pearl Harbor he was quite eager to join the Army, but initially he could not do it because he was an enemy alien, so he volunteered to be drafted and after about 6 months actually managed to get drafted. He was sent for training at a facility called Camp Ritchie, MD, part of the Military Intelligence Section (MIS): "The first question he asked me, in perfect, flawless German, 'where did you learn to speak German?' And I told him, 'the same place you did' (laughs) And you know, we spoke-but he had been

15. Colin A., interview with author, 2009.

16. Ibidem. 
naturalized, He had been in this country a little longer." 17 . In Europe, Gerd followed the frontline from France, working with the French resistance, all the way into Germany, and his job consisted in interrogating prisoners captured at the front line. It was a first line of interrogation to get strategic intelligence needed immediately in the field. He talks about how his cultural preparadness was key in intelligence gathering in the field: "We had a lot of information. Well don't forget that there were a lot of people, like myself, that had lived there. For instance, in the area around Cologne, we used to ride our bicycles there on weekends and go on day trips. And I knew it like I knew the back of my hand, you know. And there were other people from other parts of Germany that knew the area very well. There was a lot of good information that we got from people who lived there and who knew."18 With uncooperative prisoners, this is the method they used and that worked according to Gerd: "We asked them, "How tall are you?". "Uh, two meters". "Okay, start digging. Two meters, six feet deep". And they start digging. And the more they were digging, they were sweating. They didn't realize that we wanted some place to dive into if there was an attack, which there was more often than we expected. And a lot of times that worked. Because they thought, I'm digging my own grave here. The war's over. Why shouldn't I tell them? I know some other guys had difficulties making some of the prisoners work, and they used some pretty roughpretty rough methods. We didn't have waterboarding, but there were ways of - the SS were the people that gave us the hardest times. And some of them were arrogant and wouldn't give us anything but their name, rank, or serial number, or even that much. And we sent them back into the prison cage."19 Also, Gerd is German, and here he explains how his knowledge of not just the language, but also the territory, were both useful to him in his capacity of intelligence officer, and how he was able to play with his knowledge to trick the prisoners into thinking of him as omniscient - that he already knew many things so it was not worth trying to hide information.

\section{DIC: detailed interrogation}

Specific interrogation facilities were established during the war both on American or British soil, and abroad not far from the war theatres, with the precise objective of collecting 'human intelligence' by interrogating the enemy, more specifically prisoners of war or suspected spies. More specifically, these centres had the purpose of performing a second and more detailed line of interrogation with prisoners who had been selected out after the first round of questioning. Aliens arriving at ports all over Britain from allied and friendly countries or from enemy occupied areas were received at the London Reception Centre (LRC) at the Royal Victoria Patriotic School (RVPS) in Wandsworth, and submitted to a first line of interrogation, whereas aliens arriving from Germany or Italy were brought to Internment Camp 001. It was very clear that arrivals from continental Europe first of all had to supply good information, they had to be security cleared, and then they could be assisted and released to their own authorities in Britain. Almost 4 thousand interviews conducted there were used to produce official interrogation reports with useful tactical and strategic information for dissemination in the services. The other vital task of these centres was to security clear

17. Gerd M., oral history interview and transcript, Veterans History Project, Library of Congress.

18. Ibidem.

19. Ibidem. 
all those entering Britain, and those who were not clear were sent to other centres for a second and more thorough line of interrogation ${ }^{20}$. These facilities included the well known Camp 020, the centre established in 1940 by MI5 and run by Lt. Col. Stephens at Latchmere House, near Ham Common in the outskirts of West London, where many spies were interrogated and turned into double agents, and the Combined Services Detailed Interrogation Centres (CSDIC). The first nucleus of the CSDIC (UK) was in operation in the Tower of London within 24 hours of the outbreak of the conflict, but in 1942 the centre was moved to No. 1 Distribution Centre (DC), Latimer House, Buckinghamshire (which handled mainly German prisoners of war) and No. 2 DC at Wilton House, Beaconsfield, Buckinghamshire (dealing primarily with Italian prisoners). ${ }^{21}$ The charter establishing the creation of CSDIC stated that its purpose was "to submit selected prisoners of war, either Naval, Military or Air Force, or internees, to a comprehensive interrogation by specially qualified officers" ${ }^{22}$. During the course of the conflict various interrogation centres overseas were also set up, as well as a number of mobile units: in the North African theatre at Cairo and in the Mediterranean theatre at first in Naples and then in Rome. Towards the end of the conflict CSDIC facilities were set up at Diest in Belgium, near Graz in Austria, and after the end of the hostilities in Europe, at Bad Nenndorf in the British zone of occupation of Germany. CSDIC (UK) continued to work with selected prisoners including high ranking enemy officers until its closure in November $1945^{23}$.

The interrogation techniques used at these centres varied a lot according to the purpose of the centre and to the type of persons held there, e.g. refugees or prisoners of war. At the RVPS for example, aliens were not free, but they were treated as involuntary guests. Officers were instructed to use the same interrogation methods that they had learned during their intelligence training, but with a nicer approach:

Aliens were welcomed with a handshake, offered a cigarette, and put at their ease with a few friendly words of welcome to our land of liberty after their escape from a country under German rule. [...] An intelligent informant, at his ease and full of enthusiasm, needed guidance rather than interrogation ${ }^{24}$.

A card index compiled with information collected from the LRC and from other intelligence sources eventually arrived to include about 100,000 cards and it was used to cross-check any information collected, and it became one of the most useful tools for the HUMINT machinery ${ }^{25}$.

At Camp 020 and at the CSDIC centres the system was quite different. Those held there were prisoners, not unwilling guests, and they were suspected spies or war criminals. On arrival they were stripped, given a body search, dressed in prison clothes and placed in solitary confinement. There was to be "no chivalry, no gossip, no cigarettes". If prisoners turned out to be uncooperative, different systems could be used

20. Simona TовіA, "Victims of war: refugees meeting the British in the Second World War", in FoOTITT and KELLY, Languages and the military, pp. 131-147.

21. The National Archives (hereafter TNA), WO 208/4970

22. <www.nationalarchives.gov.uk/catalogue> (last accessed in May 2010).

23. FoоTITT and ToBIA, WarTalk.; on CSDIC in general also see Falko BELL, "Die deutsche Spionage ist auf Zack"'.

24. TNA, WO 208/4970.

25. TNA, KV 4/344, 139. 
such as prolonged solitary confinement, changes in approaches, stool-pigeons, associating the prisoner with another selected prisoner in a cell, and the use of concealed microphones. Eavesdropping however was not considered particularly successful at Camp 020 because prisoners were generally microphone conscious and they rarely gave away anything which they had not already said in interrogation. But at CSDIC this technique was developed further. Each cell was bugged so that the detainees' conversations could be carefully screened in search of valuable intelligence. The ideal candidate for this type of job, which in effect consisted of eavesdropping, listening to the prisoners' private conversations through microphones hidden in the light fitting, was undoubtedly a native speaker. Only a native German or Austrian could for example pick up the differences of accents and dialects and identify where each prisoner was actually from, or understand geographic or other culture-specific subjects. This became one of the most effective ways to gather useful HUMINT because prisoners were more likely to talk frankly to each other, than to an interrogator, and this system became the signature feature of CSDIC and of its strategic effectiveness ${ }^{26}$. Each operator monitored two or three cells at a time and as soon as they heard something interesting, they recorded it. Fritz, originally from Berlin, was among those refugees who later became the King's most loyal aliens, and he was recruited by the War Office and MI5 to do this type of work firstly at the CSDIC (UK) centres in Latimer and Wilton Park, and then in Bad Nenndorf:

\begin{abstract}
There was no training $[\ldots]$ he told me what I would be doing, listening to prisoners of war [...] I don't know of anybody who was thrown out because they weren't good enough, once you were there you were there. [The other people] they were all ex refugees whose mother tongue was German. [...] before that wave of new recruits in 1943 the previous people who had been doing the job had not necessarily been native speakers of German, they had been officers who spoke ... British officers who spoke German, but then in 1943 they realized that there was a vast reservoir of native German speakers in the Army from whom they could recruit people who could understand German much better than the English people. [...] that was in May 1943 [that he was sent to CSDIC] first at Letterman House in Buckinghamshire, and then in Wilton Park $[\ldots]$ they were officially called distribution centres to disguise what they were, prisoner of war camps [...] but that was not publicized, it was very secret. [...] we only listened to them when they came out of the interrogation and of course this was particularly fruitful because they would tell their cell mates what they had been asked and what they had told them and what they had not told them ${ }^{27}$.
\end{abstract}

When Fritz was made a sergeant, his job became to check the work of his colleagues, so he checked for instance the transcriptions, the records cut off from the conversations which were transcribed and then were checked by a senior ranking officer. Anything which was not important was deleted, any mistakes were corrected and only what was useful to British intelligence was retained, deciding "well, from one's knowledge, you got the knowledge on the job, and only the people who were considered capable of the job were promoted"28.

In 1941 the American Army made a study of the British Interrogation facilities which seemed to be having great impact on the conduct of the war, concluding that:

26. Simona TOBIA, "The Human in Human Intelligence", in FoOTITT and Kelly, Languages and the military; Simona TOBIA, "Victims of war. Refugees first contacts with the British in the Second World War" in FoотітT and Kelly 2012, Languages and the military; Falko BELL, "Die deutsche Spionage ist auf Zack"'.

27. Fritz L., interview with author, 2009.

28. Ibidem. 
The experience of the British during the present war appears to have demonstrated [...] that a greater certainty for obtaining proper results from the interrogation of captured submarine crews, airmen, and a limited number of selected army prisoners, was assured only when it was possible for trained officers to conduct such interrogations in a central interrogation center rather than at the time of capture. ${ }^{29}$

In other words, the British system was working and consequently Washington decided to implement something similar, establishing a specific training institution for intelligence officers at Camp Ritchie in Maryland, and a number of detention facilities on the American soil which had the specific purpose to perform the detailed interrogation of prisoners who had been selected out after a first line of questioning, as it was happening in Britain. The two main facilities were Fort Hunt in Virginia, which was more oriented towards German prisoners and the existence of which remained a well kept secret until the years 2000, and Camp Tracy in California, which was more oriented towards the interrogation of Japanese prisoners ${ }^{30}$.

John Kluge was born in a Presbyterian family in Chemnitz, Germany, and had emigrated to the US in 1922 when he was 8 years old. In 1940, at the age of 26, he enlisted in the Army, anticipating a year's service, which got extended after Dec. 7 , 1941. After he graduated from Officers Candidate School, he was shunted off to Alaska's Aleutian Islands. His break came with his next assignment: a secret post not far from the newly constructed Pentagon. Thanks to his fluency with German, he spent the rest of the war interrogating captured German officers and translating captured Nazi documents. When Kluge joined the American interrogation centre outside Washington DC, he

was active in the post called 1142, which is a secret post, [...]. And I had under me very bright young people. A lot of them were of Jewish faith who came from different parts of the Middle East or Germany or whatever. And they were promised that after the war, they would become a citizen of the United States. And they were bright. They were very assiduous. They were unusual people. ${ }^{31}$.

There he also had the chance to interrogate German generals

And I would take them in my car and show them the Pentagon. And I said to these Generals, "You know, this is the annex. The big one makes this place look small". Well, you did all kinds of things with these people. You were working on their head. But we would know from past documentation who could understand English and who could speak English and so and so. And of course, they wouldn't speak any English. I all German. And I would - we'd have a man dressed as a Russian officer, and he looked Russian -- he was Russian, and he spoke Russian. But he spoke English, too. I would say, "Look. We can't get any information out of this officer. All he would give is his rank, his serial number, and the unit he's with". And I would say to the Russian -- this was all pre-planned - 'Look. We're going to give this guy one more day. Then I'm going to turn him over to you, and you can send him to Siberia or wherever you want to send him, and let your people deal with him. "Because you know, I'm sorry I have to tell you this, we're much nicer to these people. You people are very rough". And of course, the Germans were deathly afraid of the Russians. Deathly afraid of them. So the next day, things went a lot better. ${ }^{32}$

29. NARA, RG 165, Entry 179, "The activities of two agencies of the CPM Branch, MIS, G-2, WDGS", undated.

30. See for example KleInMan, "The History of MIS-Y". and CoRbin, The history of Camp Tracy.

31. John Kluge, oral history interview and transcript, Veterans History Project, Library of Congress.

32. Ibidem. 
So far I have discussed the benefits and additional importance of cultural issues, specifically the knowledge of the enemy's language, territory and culture in more general terms. But the employment of intelligence officers with these cultural skills, and more specifically former 'enemy aliens' also had its flaws. As we have seen, their hatred of the enemy was seen as a proof of loyalty for 'enemy alien' interrogators, and this could sometimes lead to various forms of violence, especially in the handling of prisoners at interrogation centres, and the instillation of fear during interrogation. The decision makers at a higher level acknowledged very clearly that harsh techniques were not useful, but on the ground they were sometimes employed and this happened especially in the case of inexperienced interrogation officers who had been recruited precisely because of their cultural knowledge but who had not received a thorough intelligence training. Their feelings of hatred and personal life experiences have deeper impact than intelligence needs, especially towards the end of the war.

In Britain the Prisoner of War Interrogation Section (Home), (PWIS (H)) was created in June 1940 and it consisted of a number of 'cages' situated in various locations in the United Kingdom, including the infamous London District Cage at Kensington Palace Gardens, active from 1940, and headed by officers trained by Lt. Col. Alexander Scotland, head of Prisoner of War Interrogation Section (PWIS) of the Intelligence Corps; incoming enemy prisoners landing in ports were taken to the nearest 'cage', where they were identified, processed, graded and submitted to the first line of interrogation in order to extract information or to establish whether they merited further more detailed and long-range interrogation by CSDIC (UK).

The London Cage's prisoners included war crimes suspects from the SS and the Gestapo, some of 'the worst of the worst', and there were a number of reports of illtreatment and even torture, for example by Fritz Knoechlein, who wrote a long letter complaining of the treatment he received at the Cage, where he was deprived of sleep, starved, beaten and humiliated constantly. Knoechlein was a high ranking officer in the SS, and he had been responsible of the Le Paradis massacre on 27 May 1940. Scotland wrote a memoir in which he talks at length about the London Cage, and he admits to having breached repeatedly the Geneva Conventions. The book had to be submitted to censorship and was only published in 1957, after having caused a lot of distress in the Foreign Office and the MI5 ${ }^{33}$.

Lt. Richard Oliver Langham was an interrogating officer at a British CSDIC prison in Bad Nenndorf, Germany at the end of the war. Those German Jewish refugees employed there might not be expected to be wholly impartial, as the inspector conducting the investigation about some deaths at the camp wrote in his notes. In fact Langham, who was originally from Munich where he was born in 1921 and had joined the British Army in 1940, was accused and court-martialled in 1948 for ill-treatment of prisoners and 'disgraceful conduct of a cruel kind' while on duty at CSDIC in Bad Nenndorf, but he was later acquitted on all counts apparently because the prosecution failed to prove his guilt. Langham was only 25 years old when he had to face former SS in Bad Nenndorf in 1946, and when he was interviewed by the court of inquiry during the investigations, he described the way he performed his job:

My job there is that of interrogator. My normal day starts at 9 o'clock, or a quarter to 9 depending on what work I have on hand. I either spend part of the day or the whole day

33. CobAIn, Cruel Britannia, pp. 26-37; Sophie JACKSON, British interrogation techniques in the Second World War, Stroud, History Press, 2012, chapter 7. 
writing up whole records, or spending it on actual interrogation. Interrogation usually takes half of the day and the rest of the day is spent writing up and going over whatever material I have obtained during the interrogation carried out. [...] Instructions are that the actual approach to an interrogation is left to the interrogator within definitely laid down rules. I am not permitted to use any physical violence whatsoever. I can not interfere with the man's rations in any way because that is quite outside my job. I am not permitted to award any punishments to a prisoner. Anything in that line must be done through the Officer in Charge of the Section ${ }^{34}$.

The reality of life in the camp however, seemed to be quite different. During the investigation, the inspector from Scotland Yard found that conditions in the CSDIC centre were very dissimilar than those described in official papers and by Langham, whom in his witness statement seemed to recite the standing orders almost by heart. Langham, when he was himself interrogated during the investigation on CSDIC, was asked what it meant to apply 'mental pressure' to a prisoner and he candidly mentioned different types of threats involving the prisoner's life and that of his/her family. These threats were allowed by the prison's commanding staff because they were never carried out $^{35}$.

\section{Denazification and War Crimes investigations}

Towards the end of the war many former German speaking refugees were sent back to their countries of origin to work in the denazification process, particularly in investigations in preparation for war crimes trials, where growing numbers of witnesses and suspects had to be questioned. Besides investigations regarding the major war criminals for the Nuremberg trials, there were many bodies involved in investigating the thousands and thousands of so-called 'minor war criminals' who were to be tried locally by military zonal tribunals in the different zones of occupation. For example, the War Crimes Investigation Unit of the BAOR in the British Zone, the Special Air Service (SAS) or the JAG Staff pool.

Fred was a German Jewish originally from Upper Silesia, he had been inmate in Dachau before he managed to reach England and joined the Pioneer Corps. In May 1945 he was posted to an Army Interpreters' Pool in Brussels. Very few of those who worked as interpreters had had more than a basic course, and many did not even receive this. Pelican was fluent in Polish, French and English, as well as German, of course, and he was selected to proceed to Bad Oeynhausen, where the WCIU was. He attended an intensive intelligence and legal course which covered legal procedures on how to obtain sworn depositions usable in courts, how to interrogate people and basic investigation training

Lord Russell explained to me that there were large numbers of German high ranking criminals still at large. They themselves did not have a great experience because this had never happened before. Two days later I was flown back to England and landed at Stansted airport to attend an intensive intelligence and legal course. The location of it

34. TNA, FO 1005/1744, Statement by witness, 7 April 1947.

35. See also Simona TовIA "Invisible Violences, Interrogation and Representation in Post-War Germany" in Hilary FoOTiTT and Andrew KNAPP (eds), Invisible Violences? The Image-Making of Liberal Wars since 1914, London, Bloomsbury, 2013. 
was kept secret, in some place out in the wild. I was received by various officers. First of all it covered the legal procedure for how to obtain a sworn deposition from arrested persons that could then be used in court. There was a certain format to be followed: every interrogation had to start with the swearing on the Bible (Sworn before me, staff sergeant Fred Pelican of the War Crimes Special Investigation Branch, BAOR...). When the deposition finished, the same sentence had to be repeated. I was also taught how to cross examine people. I went to a course of investigation, where I learnt to consider small details of vital importance which had to be considered during interrogations, such as interrogating by using only a lamp, never with a ceiling lamp. You can instantly see the reflection on the person's face and you can instantly tell whether he is telling the truth of he is a bloody liar. They were very kind to me because they realized my potential. I was given a camera for taking photographs. The use of force was not addressed directly ${ }^{36}$.

After less than a fortnight he was back in Bad Oeynhausen. At the beginning he worked with a more qualified investigator who did not have language skills, so his tasks were mainly interpreting. After a few weeks he was sent on investigations by himself and he was given almost unlimited power: investigators could dress in uniforms or civilian clothes, wear any badge, use civilian or army vehicles, they could attach themselves to any unit and they could travel between zones and across borders. His duties covered both the investigation and the interrogation of alleged war criminals. Between cases, Pelican usually remained in the office in Bad Oeynhausen for a couple of weeks, where he had to engage in translations of documents needed to prepare the documentation for the trials ${ }^{37}$.

Henry Kissinger is probably one of the most famous German Jewish émigrés who joined the allied war effort. It was thanks to an encounter with another German émigré, Fritz Kraemer, that he was involved in intelligence work and consequently chosen to become part of the CIC, the American counter-intelligence corps. That allowed Kissinger to stay reasonably away from the frontlines when he was sent to Europe in 1944. Initially, he worked as translator-driver, but then he was assigned to "remain behind to try to discover what the enemy was planning". Moving into Germany, the CIC had the task to restore order, and because there was nobody else who spoke German, Kissinger became a town administrator and through this he became a Counter-intelligence agent with the rank of sergeant. Towards the end of the war, Kissinger was stationed in Hanover, where the CIC and his mission was to ferret out the dangerous Nazis and Gestapo members in the territories under Allied control ${ }^{38}$.

\section{Conclusions}

By the end of the Second World War interrogation had been recognized as one of the most important sources of intelligence and a systematized organization had been put in place, with a network of specialized interrogation centres and especially trained intelligence officers.

My main conclusion is that in the context examined (the European Theatre of the Second World War) the Allies faced the needs of intelligence, specifically human

36. Imperial War Museum, Sound Archive, 9,222.

37. Simona TOBIA, "The Human in Human Intelligence", in FoOTITT and KeLly, Languages and the military; Fred PelicAn, From Dachau to Dunkirk, London, Vallentine Mitchell, 1993.

38. See Walter IsAaCsOn, Kissinger, New York, Simon \& Schuster Paperbacks, 2005, pp. 39-58. 
intelligence, by employing German-speaking refugees in order to exploit their cultural knowledge. The majority of these intelligence officers were enemy aliens, and they were needed because of their cultural knowledge of the enemy, the territory, the language. The big conundrum of intelligence was to assess their loyalty and as we have seen in many cases their "implacable hatred of the enemy", shown by the fact that they had to leave their home to find refuge elsewhere and also by their strong willingness to volunteer to join the forces, was seen by their employers - such as Lt. Col. Stevens for example - as testimony of their loyalty.

The use of this type of personnel had an additional value for HUMINT, and as a consequence the American forces started to follow the same path of the British, and they incremented the use of native German speakers who were also loyal as the war progressed. This, however could sometimes lead to some problems because towards the end of the war, when the needs for cultural skills increased during occupation/liberation and denazification, and more formerly enemy aliens were employed as intelligence officers even if sometimes they had not received an appropriate training. Their cultural knowledge and hatred of the enemy were sometimes considered as more important qualifications, but this resulted in ill-treatment both in prisoner handling in the detention centres and in interrogation itself.

The next phase of this research will focus on the Pacific Theatre. The US Marines established an interrogation program in the Pacific which as early as June 1944 was able to provide the complete Japanese order of battle ${ }^{39}$. As we know, in the Pacific context, too many potential enemies - Japanese-Americans - were enrolled and performed intelligence work, particularly the Nisei soldiers. Officials had to recognize this fact to the point that they knowingly decided to use this group of enemy aliens for jobs for which their cultural backgrounds were thought to be particularly helpful. And they decided to do so despite the loyalty issues involved.

39. RosenbaCH and PeRITZ, “Confrontation or collaboration?”, p.3. 